University of Nebraska - Lincoln

DigitalCommons@University of Nebraska - Lincoln

\title{
Growing rate of gain on subsequent feedlot performance, meat, and carcass quality of beef steers
}

\author{
B. A. Loken \\ North Dakota State University \\ R. J. Maddock \\ North Dakota State University \\ M. M. Stamm \\ North Dakota State University, Hettinger \\ C. S. Schauer \\ North Dakota State University, Hettinger \\ Ivan G. Rush \\ University of Nebraska-Lincoln, irush1@unl.edu
}

See next page for additional authors

Follow this and additional works at: https://digitalcommons.unl.edu/panhandleresext

Part of the Agriculture Commons

Loken, B. A.; Maddock, R. J.; Stamm, M. M.; Schauer, C. S.; Rush, Ivan G.; Quinn, S.; and Lardy, G. P., "Growing rate of gain on subsequent feedlot performance, meat, and carcass quality of beef steers" (2009). Panhandle Research and Extension Center. 32.

https://digitalcommons.unl.edu/panhandleresext/32

This Article is brought to you for free and open access by the Agricultural Research Division of IANR at DigitalCommons@University of Nebraska - Lincoln. It has been accepted for inclusion in Panhandle Research and Extension Center by an authorized administrator of DigitalCommons@University of Nebraska - Lincoln. 


\section{Authors}

B. A. Loken, R. J. Maddock, M. M. Stamm, C. S. Schauer, Ivan G. Rush, S. Quinn, and G. P. Lardy 


\title{
Growing rate of gain on subsequent feedlot performance, meat, and carcass quality of beef steers ${ }^{1}$
}

\author{
B. A. Loken, ${ }^{*}$ R. J. Maddock, ${ }^{* 2}$ M. M. Stamm, $\dagger$ C. S. Schauer,$\dagger$ I. Rush $\ddagger$ \\ S. Quinn, + and G. P. Lardy* \\ *Department of Animal Sciences, North Dakota State University, Fargo 58108-6050; \\ $\dagger$ Hettinger Research Extension Center, North Dakota State University, Hettinger 58639; \\ and $\ddagger$ University of Nebraska Panhandle Research and Extension Center, Scottsbluff 69361
}

\begin{abstract}
Eighty Angus and Angus $\times$ Simmental steer calves were used in a completely random design to determine the effect of rate of BW gain during the backgrounding period on subsequent feedlot performance, carcass characteristics, Warner-Bratzler shear force (WBSF), and sensory analysis. Animals were stratified by BW and allotted randomly to 1 of 10 pens (5 pens/treatment). Dietary treatments were formulated for an $\mathrm{ADG}$ of $0.91 \mathrm{~kg} / \mathrm{d}$ [low BW gain (LG), 1.06 Mcal of $\mathrm{NE}_{\mathrm{g}} / \mathrm{kg}$ ] diets and $1.25 \mathrm{~kg} / \mathrm{d}$ [high $\mathrm{BW}$ gain (HG), 1.19 Mcal of $\left.\mathrm{NE}_{\mathrm{g}} / \mathrm{kg}\right]$. Steers were fed 70 $\mathrm{d}$ during the growing period. The LG diet consisted of $52.5 \%$ barley silage, $39.0 \%$ whole shell corn, and $8.5 \%$ supplement, whereas the HG diet contained $43.9 \%$ barley silage, $47.4 \%$ whole shell corn, and $8.7 \%$ supplement (DM basis). Initial BW $(226 \mathrm{~kg})$ was not different $(P=$ $0.70)$ between treatments. Steers fed the HG diet had increased ADG (1.67 vs. $1.40 \mathrm{~kg} / \mathrm{d} ; P<0.001)$ compared with steers fed LG diet. Dry matter intake was greater $(9.49$ vs. $8.35 \mathrm{~kg} / \mathrm{d} ; P<0.001)$ for steers fed the HG vs. LG diet. Total backgrounding cost (\$/animal) was less $(P<0.001)$ for those steers fed LG diet compared with HG diet (\$126.00 vs. $\$ 140.35$, respectively);
\end{abstract}

however, total cost per kilogram of $\mathrm{BW}$ gain was not different $(P=0.24 ; \$ 0.485 / \mathrm{kg}$ of BW gain). After the backgrounding period, steers were fed a common finishing diet for $135 \mathrm{~d}$. During the finishing period, LG steers had similar ( $P=0.12 ; 10.73$ vs. $10.35 \mathrm{~kg} / \mathrm{d})$ DMI compared with those fed HG diets; however, ADG was not different $(1.55 \mathrm{~kg} ; P=0.72)$ among treatments. Hot carcass weight, marbling score, 12th-rib fat, LM area, and USDA yield grade were not different $(P>$ 0.12 ) between treatments and averaged $363 \mathrm{~kg}, \mathrm{Sm}^{30}$, $1.33 \mathrm{~cm}, 83.8 \mathrm{~cm}^{2}$, and 2.7 , respectively. There were no differences $(P=0.77 ; 3.63 \pm 0.12 \mathrm{~kg})$ in WBSF tenderness of rib-eye steaks. Percent cooking loss was increased in LG diets $(P=0.017)$. No differences were observed in consumer sensory analysis of tenderness, juiciness, and flavor intensity $(P \geq 0.276 ; 5.43 \pm 0.12$, $5.07 \pm 0.13$, and $5.17 \pm 0.05$, respectively). These data suggest that feeding steers diets that differ in energy concentration and result in ADG of 1.4 and $1.7 \mathrm{~kg} / \mathrm{d}$ during the growing period results in minimal changes in subsequent finishing performance and does not affect meat quality.

Key words: finishing, growing, meat quality, rate of gain, steer, tenderness

(0)2009 American Society of Animal Science. All rights reserved.

J. Anim. Sci. 2009. 87:3791-3797 doi:10.2527/jas.2009-1853

\section{INTRODUCTION}

Backgrounding, the time period between weaning and finishing cattle, is used to prepare cattle for finishing programs and can provide a tool to improve uniformity in cattle BW and composition. Improved uniformity in slaughter cattle can be achieved by allowing calves to attain a greater BW before the start of the finishing

\footnotetext{
${ }^{1}$ The authors gratefully acknowledge the assistance of Dean Wang (Beach, ND) for his help in sourcing feeder calves for this research.

${ }^{2}$ Corresponding author: Robert.Maddock@ndsu.edu

Received January 30, 2009.

Accepted July 15, 2009.
}

phase (Vaage et al., 1998). Backgrounding calves before finishing can also increase mature size (Owens et al., 1993). Backgrounding systems typically involve feeding cattle for moderate growth, allowing for maturation of muscle and bone while restricting fat deposition (Block et al., 2001), and allow body development before finishing, allowing cattle to attain greater carcass weights at slaughter (Sainz et al., 1995). Backgrounding, more generally defined, is used by beef cattle producers for several reasons, including utilizing homegrown feeds, taking advantage of grazing opportunities, delaying finishing to target a specific market, acclimating calves to eating from bunks and drinking from a fountain waterer, or promoting skeletal growth of small-framed cattle 
(Anderson, 1991). Nutrition and management practices during the backgrounding phase are major contributors to finishing performance and carcass characteristics (Ralston et al., 1966). Previous researchers have studied the effects of backgrounding on differing breed types (Block et al., 2001), the effects of prolonged backgrounding on growth performance and carcass composition (Vaage et al., 1998), and the effects of backgrounding and growing programs on beef carcass quality (Klopfenstein et al., 1999). However, little research exists that examines the effect of rate of BW gain during backgrounding on finishing performance, carcass characteristics, and sensory traits. Therefore, this study was conducted to determine the effects of backgrounding rate of gain on subsequent feedlot performance, carcass characteristics, Warner-Bratzler shear force (WBSF), and sensory analysis.

\section{MATERIALS AND METHODS}

All animal handling and care were approved by the North Dakota State University Institutional Animal Care and Use Committee before the investigation of this research.

\section{Backgrounding Phase}

Eighty steer calves (76 Angus-sired and 4 Angus $\times$ Simmental-sired; dams were predominantly Angus genetics) from a single cow-calf producer located near Baker, MT, were used to evaluate the effects of 2 different rates of $\mathrm{BW}$ gain and its effects on growth performance and calf health during the backgrounding period. Steers were shipped $139.0 \mathrm{~km}$ from Baker to Hettinger, ND, on October 9, 2006. Steers were weighed, then stratified by initial BW (avg. $229 \pm 77 \mathrm{~kg}$ ) and allotted to 1 of 10 pens. Steers were 197 d of age at arrival and were weaned earlier in September at approximately 163 d of age. Upon arrival steers were fed a receiving diet consisting of a total mixed ration containing alfalfa hay, brome hay, oat hay, whole shelled corn, and supplement for the first $4 \mathrm{~d}$ postarrival. All steers were fed aureomycin medicated crumbles (22 mg of aureomycin/ $\mathrm{kg}$ of BW; CHS Nutrition, Sioux Falls, SD) to prevent bovine respiratory disease complex for the first $8 \mathrm{~d}$ at the feed yard.

Before initiating the study, steers were transitioned to the low BW gain ( $\mathbf{L G}$ ) to acclimate calves to silage diets and their surroundings. Dietary treatments are located in Table 1. After the 14-d adaptation period, steers were fed dietary treatments for a period of 70 d. Steers were bunk fed once daily before $0800 \mathrm{~h}$, and water was provided ad libitum. Calves were weighed on 2 consecutive days (October 23 and 24, 2006) and at the start of the study. Pens were assigned randomly to 1 of 2 dietary treatments of LG or high BW gain diet $(\mathbf{H G})$, with 5 replicate pens per treatment. Diets consisted of barley silage, whole shell corn, a supple-
Table 1. Dietary composition fed to Angus and Angus $\times$ Simmental steers during the backgrounding period

\begin{tabular}{|c|c|c|c|}
\hline \multirow[b]{2}{*}{ Item } & \multicolumn{3}{|c|}{$\operatorname{Diet}^{1}$} \\
\hline & Receiving diet & LG & $\mathrm{HG}$ \\
\hline \multicolumn{4}{|l|}{ Ingredient, \% DM basis } \\
\hline Alfalfa-grass hay & 23.0 & - & - \\
\hline Barley hay & 12.9 & - & - \\
\hline Oat hay & 13.1 & - & - \\
\hline Barley silage & - & 52.6 & 43.9 \\
\hline Whole shell corn & 43.3 & 39.0 & 47.4 \\
\hline Supplement pellets ${ }^{2}$ & 7.0 & 6.2 & 5.2 \\
\hline Deccox medicated crumbles ${ }^{3}$ & 1.5 & 1.6 & 1.3 \\
\hline Soybean meal, $44 \%$ & - & - & 1.3 \\
\hline Calcium carbonate & - & 0.7 & 0.9 \\
\hline \multicolumn{4}{|l|}{ Analyzed composition } \\
\hline DM, $\%$ & 86.6 & 50.9 & 56.7 \\
\hline Ash, \% DM basis & 9.7 & 11.5 & 10.7 \\
\hline $\mathrm{CP}, \% \mathrm{DM}$ basis & 13.5 & 13.1 & 12.2 \\
\hline $\mathrm{ADF}, \% \mathrm{DM}$ basis & 14.3 & 20.1 & 14.8 \\
\hline NDF, \% DM basis & 40.4 & 37.4 & 27.6 \\
\hline \multicolumn{4}{|l|}{ Calculated composition } \\
\hline $\mathrm{NE}_{\mathrm{m}}, \mathrm{Mcal} / \mathrm{kg}$ & 1.76 & 1.64 & 1.79 \\
\hline $\mathrm{NE}_{\mathrm{g}}, \mathrm{Mcal} / \mathrm{kg}$ & 1.01 & 1.06 & 1.19 \\
\hline \multicolumn{4}{|c|}{$\begin{array}{l}{ }^{1} \mathrm{LG}=\text { low } \mathrm{BW} \text { gain; } \mathrm{HG}=\text { high } \mathrm{BW} \text { gain. } \\
{ }^{2} \mathrm{Commercial} \text { supplement (as fed): } 27 \% \mathrm{CP} \text {; minimum } \mathrm{Ca}, 2.0 \% \text {; } \\
\text { minimum P, 0.7\%; minimum } \mathrm{K}, 0.7 \% \text { minimum vitamin } \mathrm{A}, 59,500 \\
\mathrm{IU} \cdot \mathrm{kg}^{-1} ; \text { minimum vitamin } \mathrm{D}_{3}, 3,750 \mathrm{IU} \cdot \mathrm{kg}^{-1} ; \text { minimum vitamin } \mathrm{E}, \\
221 \mathrm{IU} \cdot \mathrm{kg}^{-1} \text {; and monensin (Elanco Animal Health, Greenfield, IN), } \\
490 \mathrm{mg} \cdot \mathrm{kg}^{-1} \text {. } \\
{ }^{3} \mathrm{Deccox} \text { (Alpharma Inc., Bridgewater, NJ) medicated crumbles were }\end{array}$} \\
\hline
\end{tabular}

ment that contained monensin (Elanco Animal Health, Greenfield, IN), calcium carbonate, $44 \% \mathrm{CP}$ soybean meal, and decoquinate (Alpharma Inc., Bridgewater, NJ). The LG diet was formulated to contain 1.06 Mcal of $\mathrm{NE}_{\mathrm{g}} / \mathrm{kg}$ (target $\mathrm{ADG}=0.9 \mathrm{~kg}$ ), whereas the $\mathrm{HG}$ diet was formulated to contain 1.19 Mcal of $\mathrm{NE}_{\mathrm{g}} / \mathrm{kg}$ (target $\mathrm{ADG}=1.25 \mathrm{~kg}$ ). We also estimated that the $\mathrm{LG}$ cattle would consume an average of $2.4 \%$ of their initial BW (DM basis), whereas the HG cattle would consume $2.8 \%$ of initial BW (DM basis; NRC, 2000).

Steers were vaccinated with Bovi-Shield Gold 5 (Pfizer Animal Health, New York, NY) for bovine rhinotracheitis virus, parainfluenza-3 virus, bovine respiratory syncytial virus, and bovine viral diarrhea virus (types 1 and 2). On d 36, calves were revaccinated with Bovishield Gold 5 and vaccinated for Hemophilus somnus with Express 5-HS (Boehringer-Ingelheim Vetmedica Inc., St. Joseph, MO). Steers were implanted with a Ralgro implant (36 mg of zeranol; Schering-Plough Animal Health Corporation, Kenilworth, NJ) on d 1 of the study.

Evaluation of growth performance of steers was done by taking interim BW on d 36, 52, and 64 . After evaluation on d 52, all whole shelled corn was removed from the LG diet in an attempt to decrease the rate of BW gain. Barley silage was used on an equal DM basis to replace the whole shelled corn. Diet samples were taken on d 2, 20, 42, 55, and 66. Diet samples were composited by pen and analyzed for DM, ash, CP, NDF, 
Table 2. Dietary composition fed to Angus and Angus $\times$ Simmental steers during the finishing period

\begin{tabular}{|c|c|c|c|c|c|}
\hline \multirow[b]{2}{*}{ Item } & \multicolumn{5}{|c|}{ Diet } \\
\hline & Step 1 & Step 2 & Step 3 & Step 4 & Final \\
\hline \multicolumn{6}{|c|}{ Ingredient, \% DM basis } \\
\hline Corn silage & 24.6 & 18.9 & 13.5 & 8.1 & 3.1 \\
\hline Dry rolled corn & 36.1 & 48.4 & 60.5 & 73.0 & 81.2 \\
\hline Alfalfa hay & 32.1 & 24.6 & 17.6 & 10.5 & 7.3 \\
\hline Supplement ${ }^{1}$ & 7.2 & 8.1 & 8.4 & 8.4 & 8.4 \\
\hline \multicolumn{6}{|c|}{ Formulated composition } \\
\hline $\mathrm{DM}, \%$ & 64.2 & 68.7 & 73.3 & 78.6 & 84.3 \\
\hline $\mathrm{CP}, \%$ DM basis & 15.2 & 14.9 & 14.5 & 13.8 & 13.5 \\
\hline
\end{tabular}

$\mathrm{ADF}, \mathrm{Ca}, \mathrm{P}, \mathrm{K}$, and nitrate concentration using AOAC (2000) procedures at a commercial laboratory certified by the National Forage Testing Association (Midwest Laboratories, Omaha, NE).

\section{Finishing Phase}

During the backgrounding period, 2 steers assigned to the HG treatment died due to reasons unrelated to the study. Seventy-eight steers were shipped to University of Nebraska Panhandle Research and Extension Center feedlot in Scottsbluff for finishing on January 2, 2007. Upon arrival steers were reassigned within treatments to 1 of 10 pens, containing 7 or 8 steers per pen. Pen reassignment was caused by a communication error; however, because steers were fed a common finishing diet, and any potential biological effect of the LG and HG diets would have been manifested regardless of subsequent pen assignment, we believe the reassignment did not affect results. During the finishing period, 2 steers (1 from each treatment) died of urinary calculi.

All steers were fed a common finishing diet (Table 2 ). Five steps were used to transition cattle to the finishing ration. The finishing diet consisted of dryrolled corn, alfalfa hay, corn silage, and a supplement that contained monensin and tylosin (Elanco Animal Health). Feed refusals were recorded weekly to determine DMI. Steers were implanted on Feb. 21, 2007 with Revalor-S (trenbolone acetate-estradiol; Hoechst Roussel Vet, Overland Park, KS). Finishing endpoint was determined by ultrasonic evaluations of 12th-rib fat. When the average fat depth of one-third of all calves was determined to be $1.14 \mathrm{~cm}$, calves were marketed for slaughter at a commercial abattoir.

\section{Slaughter Collection}

On May 20, 2007, steers were shipped to Greeley, CO, for processing. Steers were slaughtered on May 21, 2007. Carcasses were chilled at $1 \pm 2^{\circ} \mathrm{C}$ for $48 \mathrm{~h}$ then ribbed between the 12th and 13th ribs before carcass data was collected. The LM area was measured with a plastic grid (Art Services, Washington, DC. Kidney, pelvic, and heart; marbling score; lean maturity; and skeletal maturity were assessed visually, and preliminary yield grade was determined to the nearest 0.1 of a grade using a metal ruler (USDA, 1997). Fat thickness was calculated from adjusted preliminary yield grade. Quality grade and yield grade were recorded from a USDA grader. Meat samples $(5.1 \mathrm{~cm}$ thick $)$ were removed from the loin on the right side of each carcass starting at the 13th rib. Meat samples were transported to North Dakota State University where they were vacuum packaged and aged for $14 \mathrm{~d}$ from the slaughter date at $2^{\circ} \mathrm{C}$. Meat samples were then frozen $\left(-20^{\circ} \mathrm{C}\right)$ until shear force and sensory analysis could be conducted.

\section{$W B S F$}

Meat samples were cut into two 2.54-cm-thick steaks by a bandsaw before thawing. One steak was repackaged and returned immediately to the freezer, whereas the other was allowed to thaw for $24 \mathrm{~h}$ at $5^{\circ} \mathrm{C}$. External fat was removed from the thawed steaks, and the steaks were cooked in a convection oven set at $165^{\circ} \mathrm{C}$ to an internal temperature of $70 \pm 3^{\circ} \mathrm{C}$. Temperatures and weights were recorded before and immediately after cooking. After cooking, steaks were cooled for 3 to 4 $\mathrm{h}$, until they reached room temperature (approximately $20^{\circ} \mathrm{C}$ ). Six $1.27-\mathrm{cm}$ cores were removed from each steak parallel to the muscle fiber orientation. Each core was sheared perpendicular to the muscle fiber orientation with a Warner-Bratzler machine (G-R Manufacturing Co., Manhattan, KS), and peak shear force measurements were recorded and averaged to obtain a single WBSF value for each steak.

\section{Sensory Analysis}

Before this study, the sensory analysis protocol was approved by the North Dakota State University Institu- 
Table 3. Effects of rate of BW gain on backgrounding performance of steers

\begin{tabular}{|c|c|c|c|c|}
\hline \multirow[b]{2}{*}{ Item } & \multicolumn{2}{|c|}{ Treatment $^{1}$} & \multirow[b]{2}{*}{ SEM } & \multirow[b]{2}{*}{$P$-value } \\
\hline & LG & $\mathrm{HG}$ & & \\
\hline No. of pens & 5 & 5 & - & - \\
\hline No. of steers & 39 & 37 & - & - \\
\hline Initial BW, kg & 256.2 & 257.3 & 2.3 & 0.700 \\
\hline End $\mathrm{BW}, \mathrm{kg}$ & 353.2 & 374.5 & 4.1 & $<0.001$ \\
\hline $\mathrm{ADG}, \mathrm{kg}$ & 1.40 & 1.67 & 0.04 & 0.001 \\
\hline DMI, kg & 8.35 & 9.49 & 0.10 & $<0.001$ \\
\hline DMI, \% BW & 2.76 & 3.03 & 0.05 & 0.006 \\
\hline $\mathrm{G}: \mathrm{F}$ & 0.17 & 0.18 & $<0.01$ & 0.225 \\
\hline Feed cost, $\$ /$ animal $^{2}$ & 95.95 & 110.68 & 1.05 & $<0.001$ \\
\hline Total cost, $\$ /$ animal $^{3}$ & 126.00 & 140.35 & 1.31 & $<0.001$ \\
\hline Feed cost, $\$ / \mathrm{kg}$ of BW gain & 1.00 & 0.97 & 0.03 & 0.394 \\
\hline Total cost, $\$ / \mathrm{kg}$ of BW gain & 1.09 & 1.05 & 0.03 & 0.248 \\
\hline
\end{tabular}

tional Review Board. Thawing and cooking procedures were the same as those used for shear force measurement. Steaks were selected randomly for each daily taste panel. After cooking, steaks were allowed to set at room temperature for $5 \mathrm{~min}$ to equilibrate. Steaks were wrapped in plastic wrap and placed in a $23^{\circ} \mathrm{C}$ oven until samples were cut. Steaks were cut into $1.27 \times 2.54 \mathrm{~cm}$ pieces, and all external fat and connective tissue was removed. Samples were placed in a covered container and served to each panelist.

Panelists were given 2 cups; the first was filled with distilled water, and the other was empty for sample expectoration. Each panelist was also given unsalted saltine crackers, toothpicks, and a ballot (AMSA, 1995). The same sample was given to each panelist at the same time. Panelists were first asked to take a bite of cracker and a sip of water to cleanse their palate before starting and between each sample. Panelists were trained to determine tenderness, juiciness, flavor intensity, and off-flavor of each sample (AMSA, 1995). Tenderness, juiciness, and flavor intensity were on a rated scale of 1 to 8 , with 1 being extremely tough, dry, and flavorless, and 8 being extremely tender, juicy, and flavorful.

\section{Statistical Analysis}

Backgrounding, finishing, carcass, and meat data was analyzed as a completely randomized design using the MIXED procedures (SAS Inst. Inc., Cary, NC). Least squares means were calculated, and means were considered to be significant at the $P<0.05$ level. Pen was used as the experimental unit for all data, with 5 pens per treatment used for replication. Data for sensory analysis were averaged by individual animal and then averaged by pen. The model included the fixed effect of feeding treatment and the random effect of pen replicate.

\section{RESULTS AND DISCUSSION}

\section{Backgrounding Performance}

Backgrounding performance is shown in Table 3 . Initial BW did not differ between treatments $(P=$ 0.701). By design, ADG was greater for the HG treatment than for those on the LG treatment $(P<0.001)$, and therefore, backgrounding final BW were greater for steers on the HG treatment $(P<0.001)$. Average daily gain was greater for both treatments than what was initially projected, due to the cattle consuming more than what was estimated. The LG diet consumed $2.8 \%$ of their initial BW (DM basis), whereas HG diet consumed $3.0 \%$ of their initial BW (DM basis). In our study, we observed increased DMI $(P<0.001)$ and increased DMI as a percentage of $\mathrm{BW}(P=0.006)$ for the HG treatment. There was no effect on G:F due to treatment $(P=0.225)$. In contrast to our results, Coleman et al. (1995) reported decreased G:F with increased DMI for steers consuming silage-based diets at a slower rate of BW gain compared with steers fed grain-based diets formulated to have increased rate of BW gain.

Feed costs accounted for approximately $75 \%$ of the total costs during the backgrounding period. No differences were observed in miscellaneous costs between LG and HG treatments, but feed costs and total costs were increased $(P<0.001)$ in the HG treatment. However, feed and total costs per kilogram of BW gain were not affected by treatment $(P \geq 0.248)$. Our data agree with that of Mader and Clanton (1985) who reported increased costs of feed during the growing period when grain was added in the ration at $0,0.5$, and $1 \%$ of $\mathrm{BW}$. Mader and Clanton (1985) also found an increased cost per kilogram of BW gain with the addition of concentrate, which differs from our findings. 
Table 4. Effects of backgrounding rate of BW gain on finishing performance of steers

\begin{tabular}{lcccc}
\hline \hline & \multicolumn{2}{c}{ Treatment $^{1}$} & & \\
\cline { 2 - 3 } Item & LG & HG & SEM & $P$-value \\
\hline No. of pens & 5 & 5 & - & - \\
No. of steers & 39 & 37 & - & - \\
Days on feed & 135 & 135 & - & - \\
Initial BW, kg & 355.2 & 374.5 & 6.6 & 0.073 \\
Final BW, kg & 563.8 & 582.5 & 8.9 & 0.175 \\
DMI, kg & 10.73 & 10.35 & 0.16 & 0.121 \\
ADG, kg & 1.55 & 1.54 & 0.03 & 0.718 \\
G:F & 0.14 & 0.15 & $<0.01$ & 0.304 \\
Feed cost, $\$ /$ animal $^{2}$ & 344.72 & 315.61 & 7.35 & 0.023 \\
Total cost, $\$ /$ animal $^{3}$ & 395.71 & 366.59 & 10.39 & 0.023 \\
Feed cost, $\$ / \mathrm{kg} \mathrm{of} \mathrm{BW} \mathrm{gain}_{\text {Total cost, } \$ / \mathrm{kg}^{2} \text { of BW gain }}$ & 1.69 & 1.47 & 0.07 & 0.011 \\
\hline
\end{tabular}

${ }^{1} \mathrm{HG}=$ high $\mathrm{BW}$ gain diet; $\mathrm{LG}=$ low $\mathrm{BW}$ gain diet.

${ }^{2}$ Corn silage $=\$ 0.05 / \mathrm{kg}$; dry-rolled corn $=\$ 0.18 / \mathrm{kg}$; alfalfa hay $=\$ 0.14 / \mathrm{kg} ;$ supplement $=\$ 0.31 / \mathrm{kg}$.

${ }^{3}$ Yardage $=\$ 0.35 /$ head per $\mathrm{d}$; veterinary costs $=\$ 3.71 /$ head.

\section{Finishing Performance}

Finishing performance is reported in Table 4. Upon arrival at the feedlot in Scottsbluff, NE, steers were realloted to pens within their respective treatments; therefore, initial BW had a tendency $(P=0.073)$ to be increased in the HG treatment. Steers in the HG treatment continued to have a tendency of greater BW $(P \geq 0.051)$ compared with the LG treatment throughout the finishing period (data not shown). Final BW, which was back calculated from $\mathrm{HCW}$, was not affected by treatment $(P=0.175)$. Our research found that backgrounding treatment had no effect on DMI, ADG, or G:F during the finishing period $(P \geq$ 0.121). When comparing low, medium, and high rates of winter BW gain during the backgrounding period, Neel et al. (2007) reported that cattle fed to achieve a low rate of BW gain during backgrounding had the greatest ADG during the finishing period, whereas cattle fed to achieve a high rate of BW gain had the least ADG during the finishing period. Coleman et al. (1995) reported initial ADG increased in the feedlot with steers grown on a slower rate of BW gain (silagebased diet) compared with steers grown at a greater rate of BW gain (grain-based diet). Increased DMI and G:F were reported in steers fed roughage-based diets compared with steers fed high-concentrate diets during the growing period (Sainz et al., 1995). Block et al. (2001) reported increases in ADG and DMI during the finishing period when backgrounding length was increased, which decreased G:F. However, data reported by Klopfenstein et al. (1999) agree with our data. Those researchers reported no differences in finishing ADG, DMI, and G:F when winter BW gain differed. The relatively small difference in growth rate between the LG and HG treatments in this study indicate that any differences would be subtle. In our study, feed and total costs were increased for the LG treatment $(P=$ 0.023). Feed and total cost per kilogram of BW gain was also increased in the LG treatment group $(P \leq$ 0.012). Mader and Clanton (1985) reported decreased feed costs for finishing steers that received grain during the growing period; however, feed cost per unit of BW gain were not affected due to increased grain during the growing period. Griffin et al. (2007) reported increased feed costs when calves were placed directly on to feed when compared with yearlings that were grazed during the winter and summer; however, no differences were reported in cost per kilogram of BW gain.

\section{Carcass Characteristics}

Hot carcass weights were not affected $(P=0.123)$ by treatment (Table 5). Feeding strategy and length of the backgrounding can alter HCW as reported by Block et al. (2001) who reported increased HCW when the length of the backgrounding period was increased and Vaage et al. (1998) who found that forage-based diets resulted in increased HCW when compared with highenergy diets during the backgrounding period. Because the length of background time and the treatment diets were not substantially different, it is not surprising that there were not HCW differences. Also, treatment had no effect on ribeye area $(P=0.985)$, which is in agreement with other reports in the literature. Restricted intakes during the growing phase did not affect ribeye area (Loerch, 1990), and extended backgrounding did not affect ribeye area (Vaage et al., 1998). All carcass composition and quality traits, including 12 th-rib fat, $\mathrm{KPH}$, marbling score, and USDA quality and yield grades were unaffected by treatments $(P \geq 0.12)$. Lack of change in carcass traits is in agreement with Klopfenstein et al. (1999), who reported that rate of winter BW gain did not affect USDA quality and yield grades, and Duckett et al. (2007), who found total lipid content of LM was not affected by growth rate during the stocker phase. The protocol for this project differed substantially from Klopfenstein et al. (1999) and Duckett et al. 
Table 5. Effects of backgrounding rate of BW gain on carcass characteristics of steers

\begin{tabular}{|c|c|c|c|c|}
\hline \multirow[b]{2}{*}{ Item } & \multicolumn{2}{|c|}{ Treatment $^{1}$} & \multirow[b]{2}{*}{ SEM } & \multirow[b]{2}{*}{$P$-value } \\
\hline & LG & HG & & \\
\hline No. of pens & 5 & 5 & - & - \\
\hline No. of steers & 39 & 37 & - & - \\
\hline $\mathrm{HCW}, \mathrm{kg}$ & 357 & 368 & 4.87 & 0.123 \\
\hline Rib-eye area, $\mathrm{cm}^{2}$ & 83.8 & 83.8 & 1.12 & 0.985 \\
\hline 12 th rib fat, $\mathrm{cm}$ & 1.32 & 1.33 & 0.06 & 0.914 \\
\hline $\mathrm{KPH}, \%$ & 2.50 & 2.50 & 0.07 & 0.946 \\
\hline Marbling score ${ }^{2}$ & 421 & 435 & 9.85 & 0.358 \\
\hline USDA yield grade & 2.66 & 2.74 & 0.12 & 0.651 \\
\hline USDA quality grade ${ }^{3}$ & 155 & 175 & 7.58 & 0.126 \\
\hline $\mathrm{SMAT}^{4}$ & 47.8 & 49.5 & 1.2 & 0.341 \\
\hline LMAT $^{4}$ & 46.4 & 47.3 & 0.9 & 0.542 \\
\hline
\end{tabular}

(2007) because the backgrounding period was shorter and the steers gained $\mathrm{BW}$ at a greater rate; however, in general the literature supports a lack of change in carcass traits due to treatments applied during growing or backgrounding.

\section{$W B S F$}

Shear force evaluation is presented in Table 6. Steaks were all cooked to a uniform temperature. There was no effect on percent thaw loss due to treatment $(P=$ 0.545 ); however, the LG treatment resulted in increased percent cooking loss $(P=0.017)$. Treatment had no effect on shear force analysis $(P=0.766)$. This is similar to other research in which backgrounding growth rate of BW gain had no effect on shear force analysis (Duckett et al., 2007). Coleman et al. (1995) fed growing steers a silage-based diet at a slower rate of $\mathrm{BW}$ gain or a grain-based diet at a greater rate of gain, evaluated steaks for WBSF, and reported steaks from steers fed grain were more tender than steaks from steers fed silage. In their research, 8 steers were slaughtered at the end of the growing period and 8 steers were slaughtered at 45, 75, and $105 \mathrm{~d}$ of the finishing period. At $\mathrm{d}$ 0 of finishing, meat samples from silage-fed steers were considered tough; this continued through finishing until d 105 of finishing. Hendrick et al. (1983) studied the effects of feeding cattle grain on sensory characteristics compared with cattle grown and finished on pasture and reported no differences in WBSF values for steers fed corn for any length of time.

\section{Sensory Analysis}

Sensory panel ratings of tenderness were not affected by treatment (Table $7 ; P>0.606$ ). Treatment had no effect on flavor $(P=0.875)$ or juiciness $(P=0.276)$. Off-flavor was not affected by treatment $(P=0.429)$. Duckett et al. (2007) reported no difference in tenderness and flavor due to rate of BW gain during the stocker phase. However, Coleman et al. (1995) reported steers fed to achieve a greater rate of BW gain with a grain-based diet during the growing phase had greater flavor intensity, less off-flavor, and were more tender than steaks from steers fed to achieve a slower rate of BW gain using a silage-based diet. Again, with the relatively small differences in BW gain between the LG and HG treatments, differences in sensory traits would likely be minimal. However, the potential for increased levels of protein turnover due to increased growth during backgrounding, and potential differences of intramuscular fat content due to growth differences existed.

Table 6. Effects of backgrounding rate of BW gain on cooking characteristics and Warner-Bratzler shear force of steers

\begin{tabular}{|c|c|c|c|c|}
\hline \multirow[b]{2}{*}{ Item } & \multicolumn{2}{|c|}{ Treatment $^{1}$} & \multirow[b]{2}{*}{ SEM } & \multirow[b]{2}{*}{$P$-value } \\
\hline & LG & HG & & \\
\hline Cooked steak temp, ${ }^{\circ} \mathrm{C}$ & 74.73 & 73.70 & 0.81 & 0.366 \\
\hline Thaw loss, \% & 1.58 & 2.38 & 0.59 & 0.545 \\
\hline Cook loss, $\%$ & 31.04 & 29.43 & 0.05 & 0.017 \\
\hline Shear force, $\mathrm{kg}$ & 3.59 & 3.66 & 0.12 & 0.453 \\
\hline
\end{tabular}

${ }^{1} \mathrm{HG}=$ high $\mathrm{BW}$ gain diet; $\mathrm{LG}=$ low $\mathrm{BW}$ gain diet. 
Table 7. Effects of backgrounding rate of BW gain on consumer sensory analysis of steers

\begin{tabular}{|c|c|c|c|c|}
\hline \multirow[b]{2}{*}{ Item } & \multicolumn{2}{|c|}{ Treatment $^{1}$} & \multirow[b]{2}{*}{ SEM } & \multirow[b]{2}{*}{$P$-value } \\
\hline & $\mathrm{HG}$ & LG & & \\
\hline Tenderness $^{2}$ & 5.38 & 5.48 & 0.12 & 0.606 \\
\hline Juiciness $^{2}$ & 4.96 & 5.17 & 0.13 & 0.276 \\
\hline Flavor $^{2}$ & 5.16 & 5.17 & 0.05 & 0.875 \\
\hline Off-flavor $^{3}$ & 3.98 & 3.97 & 0.01 & 0.429 \\
\hline
\end{tabular}

${ }^{1} \mathrm{HG}=$ high $\mathrm{BW}$ gain diet; $\mathrm{LG}=$ low $\mathrm{BW}$ gain diet.

${ }^{2} 1=$ extremely tough, dry, bland; $8=$ extremely tender, juicy, flavorful.

${ }^{3} 1$ = extreme off-flavor; 4 = no off-flavor.

\section{Summary}

Growth rate during backgrounding of cattle may affect subsequent growth, carcass, and meat traits. In this study, differences in intake and ADG during backgrounding did not cause differences in later growth rates, efficiencies of BW gain, or carcass or meat traits. Despite the differences in BW gain, it is possible there was not enough difference between LG and HG treatments during backgrounding to cause changes.

\section{LITERATURE CITED}

AMSA. 1995. Research Guidelines for Cookery, Sensory Evaluation and Instrumental Tenderness Measurements of Fresh Meat. Am. Meat Sci. Assoc., Champaign, IL.

Anderson, P. 1991. Optimum forage use in beef cattle growing and finishing diets. http://www.extension.umn.edu/beef/components/publications/bcmu18.pdf Accessed Feb. 29, 2008.

AOAC. 2000. Official Methods of Analysis. 17th ed. Vol. 2. Assoc. Off. Anal. Chem., Gaithersburg, MD.

Block, H. C., J. J. McKinnon, A. F. Mustafa, and D. A. Christensen. 2001. Manipulation of cattle growth to target carcass quality. J. Anim. Sci. 79:133-140.

Coleman, S. W., R. H. Gallavan, C. B. Williams, W. A. Phillips, J. D. Volesky, S. Rodriguez, and G. L. Bennett. 1995. Silage or limit-fed grain growth diets for steers: I. Growth and carcass quality. J. Anim. Sci. 73:2609-2620.
Duckett, S. K., J. P. S. Neel, R. N. Sonor Jr., J. P. Fontenot, W. M. Clapham, and G. Scaglia. 2007. Effect of winter stocker rate of gain and finishing system on: II. Ninth-tenth-eleventhrib composition, muscle color, and palatability. J. Anim. Sci. 85:2691-2698.

Griffin, W. A., T. J. Klopfenstein, G. E. Erickson, D. M. Feuz, and J. C. MacDonald. 2007. Comparison of a long yearling system and calf-fed performance and economics. Nebraska Beef Report. 58-60. Univ. Nebraska, Lincoln.

Hendrick, H. B., J. A. Paterson, A. G. Matches, J. D. Thomas, R. E. Morrow, W. C. Stringer, and R. J. Lipsey. 1983. Carcass and palatability characteristics of beef produced on pasture, corn silage and corn grain. J. Anim. Sci. 57:791-801.

Klopfenstein, T., R. Cooper, D. J. Jordon, D. Shain, T. Milton, C. Calkins, and C. Rossi. 1999. Effects of backgrounding and growing programs on beef carcass quality and yield. J. Anim. Sci. E33. http://asas.org/JAS/symposia/proceedings/0942.pdf Accessed Jan. 31, 2008.

Loerch, S. C. 1990. Effects of feeding growing cattle high-concentrate diets at a restricted intake on feedlot performance. J. Anim. Sci. 68:3086-3095.

Mader, T., and D. Clanton. 1985. Effect of implant on pre, postweaning performance. Nebraska Beef Report. 41-43. Univ. Nebraska, Lincoln.

Neel, J. P. S., J. P. Fontenot, W. M. Clapham, S. K. Duckett, E. E. D. Felton, G. Sceglia, and W. B. Bryan. 2007. Effects of winter stocker growth rate and finishing system on: I. Animal performance and carcass characteristics. J. Anim. Sci. 85:20122018.

NRC. 2000. Nutrient Requirements of Beef Cattle. 7th ed. Natl. Acad. Press, Washington, DC.

Owens, F. N., P. Dubeski, and C. F. Hanson. 1993. Factors that alter the growth and development of ruminants. J. Anim. Sci. 71:3138-3150.

Ralston, A. T., W. H. Kennick, T. P. Davidson, and K. E. Rowe. 1966. Effect of prefinishing treatment upon finishing performance and carcass characteristics of beef cattle. J. Anim. Sci. $25: 29-33$.

Sainz, R. D., F. De La Torre, and J. W. Oltjen. 1995. Compensatory growth and carcass quality in growth-restricted and refed beef steers. J. Anim. Sci. 73:2971-2979.

USDA. 1997. United States Standards for Grades of Carcasses. Agric. Market. Serv., USDA, Washington, DC.

Vaage, A. S., D. H. McCartney, J. J. McKinnon, and R. D. Bergen. 1998. Effect of prolonged backgrounding on growth performance and carcass composition of crossbred beef steers. Can. J. Anim. Sci. 78:359-367. 